\title{
Invasive alien species on islands: impacts, distribution, interactions and management
}

THEMATIC SECTION

Humans and Island

Environments

\begin{abstract}
JAMES C. RUSSELL*1,2,3, JEAN-YVES MEYER ${ }^{4}$, NICK D. HOLMES ${ }^{5}$ AND SHYAMA PAGAD ${ }^{6}$

${ }^{1}$ School of Biological Sciences, University of Auckland, Private Bag 92019, Auckland 1142, Nem Zealand, ${ }^{2}$ Department of Statistics, University of Auckland, Private Bag 92019, Auckland 1142, Nem Zealand, ${ }^{3}$ Zero Invasive Predators, c/o Zealandia Sanctuary, PO Box 9267, Wellington 6141, Nem Zealand, ${ }^{4}$ Délégation à la Recherche, Gouvernement de la Polynésie Française, BP 20981, Papeete, Tahiti, French Polynesia, ${ }^{5}$ Island Conservation, 2100 Delamare Ave Suite 1, Santa Cruz, CA 95060, USA and ${ }^{6}$ IUCN ISSG, University of Auckland, Private Bag 92019, Auckland 1142, Nem Zealand

Date submitted: 17 February 2017; Date accepted: 8 May 2017; First published online 12 June
\end{abstract} 2017

\section{SUMMARY}

Invasive alien species (IASs) on islands have broad impacts across biodiversity, agriculture, economy, health and culture, which tend to be stronger than on continents. Across small-island developing states (SIDSs), although only a small number of IASs are widely distributed, many more, including those with greatest impact, are found on only a small number of islands. Patterns of island invasion are not consistent across SIDS geographic regions, with differences attributable to correlated patterns in island biogeography and human development. We identify 15 of the most globally prevalent IASs on islands. IAS impacts on islands are exacerbated through interactions with a number of other global change threats, including over-exploitation, agricultural intensification, urban development and climate change. Biosecurity is critical in preventing IAS invasion of islands. Eradication of IASs on islands is possible at early stages of invasion, but otherwise is largely restricted to invasive mammals, or otherwise control is the only option. Future directions in IAS management and research on islands must consider IASs within a broader portfolio of threats to species, ecosystems and people's livelihoods on islands. We advocate for stronger collaborations among island countries and territories faced with the same IASs in similar socio-ecological environments.

Keymords: invasive, introduced, eradication, island, SIDS, biosecurity

\section{INTRODUCTION}

Invasive alien species (IASs) are species introduced outside their native range by human action that go on to have

*Correspondence: Dr James C. Russell email: j.russell@auckland. ac.nz significant negative impacts on the recipient environment (Jeschke et al. 2014; Russell \& Blackburn 2017), primarily on biodiversity values and ecosystem services. They differ from pest species, which might be either native or introduced, and primarily impact agricultural values, although a species can be both a pest and invasive when it impacts the entire suite of values. For those islands of the world that have only been colonized by humans recently (in the past millennium), the delineation of when human biotic disturbance and introduction of species first occurred is most clear (Delgado et al. in press), and IASs are only the subset of introduced species that have overwhelmingly negative impacts; in other words, cross a damage threshold to biodiversity values (Bartz et al. 2010).

Although there are many studies of IASs on islands, most of these have been taxon specific and focused on IAS impacts and management (e.g. Courchamp et al. 2003; Jones et al. 2016; McCreless et al. 2016). Reaser and colleagues (2007) comprehensively reviewed the ecological and socioeconomic impacts of IASs on islands. Other studies have compared invasions on continents to islands from biological (e.g. Vitousek 1988; D'Antonio \& Dudley 1995) and macroecological perspectives (van Kleunen et al. 2015; Bellard et al. 2016). In this review, we broaden the scope of previous reviews of IASs on islands by summarizing both the impacts and distribution of IASs on islands, their interactions and their management. We outline the diverse impacts IASs can have on islands, and then using a novel dataset of IAS distributions on United Nations small-island developing states (SIDSs) investigate patterns in IAS distribution across geographic regions on this subset of islands. We examine how IASs on islands interact with other major global change threats, and then discuss the roles of biosecurity, control and eradication in IAS management on islands. We conclude with future directions in IAS research and management specifically focused on islands.

\section{IMPACTS}

On islands, IASs have disproportionate impacts compared to on continents (Vitousek 1988; Bellard et al. 2016), and native

This is an Open Access article, distributed under the terms of the Creative Commons Attribution licence (http://creativecommons.org/licenses/by/4.0/), which permits unrestricted re-use, distribution, and reproduction in any medium, provided the original work is properly cited. 
species on islands are disproportionately vulnerable to IASs compared to other threats because of attributes including a lack of behavioural, life-history and certain morphological characteristics (Vitousek 1988; Tershy et al. 2015). The impacts of IASs on islands are often more readily demarcated, particularly when confounding threats are absent (e.g. Towns et al. 2006). Historically, the focus of IAS impacts has been on biodiversity values, but vulnerability on islands to IAS impacts also extends to agriculture, economies, health and cultures. These have tended to be under-considered compared to, or considered independently of, their ecological impacts on species and ecosystems. We briefly summarize the broad forms of IAS impacts under each of these headings, but refer readers to the extensive review of IAS impacts on islands by Reaser et al. (2007).

\section{Biodiversity}

The small size of islands leads to smaller populations, and their isolation creates evolutionary distinctiveness (Losos \& Ricklefs 2009), species impoverishment (Simberloff 2000) and taxonomic disharmony (Williamson 1981) with the absence of some functional groups (Cushman 1995), which together create greater vulnerability to the impacts of IASs (Vitousek 1988; Tershy et al. 2015). IASs generate negative impacts through a number of trophic and ecosystem interaction pathways. Introduced predators, such as terrestrial mammals or invertebrates, can induce strong predator-prey dynamics and rapidly cause the extirpation (i.e. local extinction) of native species populations. Introduced competitors, such as birds, reptiles and plants, can alter competition dynamics and cause reductions in the abundance, or sometimes extirpations, of native species populations. In some cases, IASs can subsidize other native and introduced species in ecosystems (Roemer et al. 2002; Abernethy et al. 2016) and participate in novel indirect effects (Russell 2011).

There are many examples of extinctions or extirpations of endemic animal species (land birds, reptiles, land snails and aquatic insects) caused by the introduction of predators (rats, cats, mongooses, snakes, carnivorous snails, freshwater fishes, ants and raptors). The introduction of herbivores (e.g. rabbits, feral goats, sheep, deer, pigs, horses and cattle) can impact native island vegetation as well as cause habitat loss and erosion and alter nutrient dynamics. The impacts of invasive plants are less documented and more difficult to assess (with very few if any native plant extinctions), but plant and animal invaders can contribute to alterations of both ecosystem services and dynamics (e.g. soil erosion, nutrient cycling, fire regime and water content; Fukami et al. 2006; Meyer 2014; Downey \& Richardson 2016).

\section{Agriculture}

Agriculture on islands relies on the local environment, although the products themselves are often non-native. This production typically benefits from island isolation and the absence of pests (mainly weeds, arthropods and pathogens) found elsewhere. Indeed, many IASs are also agricultural pests, and thus their exclusion benefits both agriculture and biodiversity. The costs of IASs to agriculture in the USA have been estimated at over US $\$ 120$ billion per year (Pimentel et al. 2005), and for invasive insects globally at over US $\$ 70$ billion per year (Bradshaw et al. 2016), but estimates for IAS impacts on islands are decidedly lacking (though see Mwebaze et al. 2010). Island biosecurity benefits from the duality of IASs and agricultural pests, which can lead to strong border controls against IASs (e.g. Kriticos et al. 2005), but species impoverishment on islands has been a primary driver of species introductions in the past, such as those by acclimatization societies, forestry departments, and botanical gardens (Veltman et al. 1996; Hulme 2011). Agricultural introductions can thus be major sources of new IASs on islands (Driscoll et al. 2014), including escaped livestock and animal species being introduced for putative biocontrol without hostspecificity tests (Secord \& Kareiva 1996; Simberloff \& Stiling 1996).

\section{Economy}

Like their ecosystems, island economies tend to be less diversified (Briguglio 1995). Particularly for SIDSs, there is often a reliance on only a few revenue streams, which are often tightly coupled with the terrestrial and marine environments (Pelling \& Uitto 2001). Disruption of these ecological environments thus has downstream impacts on island economies, in the worst cases potentially causing complete collapses of industries (Bunce et al. 2009). More recently, tourism has become a major component of island livelihoods (Wilkinson 1987). Although much tourism on islands is generally independent of ecological values, ecotourism draws specifically from the isolation and ecological uniqueness of islands (Uyarra et al. 2005), and thus biotic homogenization from species introduction and invasion directly erodes trade and tourism value (Jay et al. 2003).

\section{Health}

Due to lack of previous exposure, both human and non-human island communities are more vulnerable to introduced diseases (Daszak et al. 2000; Crump et al. 2001). Whereas the impact of foreign diseases on human communities on islands is well recorded (Mazza et al. 2014), the effect of introduced diseases on biodiversity is less well appreciated (Young et al. 2017). However, there are striking examples of introduced diseases that are severely impacting the persistence of island species (Beever et al. 2009). Furthermore, some IASs introduced to islands can be vectors for diseases, amplifying IAS impacts (e.g. introduced birds and avian malaria, rodents and leptospirosis, and mosquitoes and flaviviruses). Management of IASs is predicted to create important improvements in public health alongside biodiversity (de Wit et al. 2017). 


\section{Culture}

The factors that generate unique species assemblages on islands also generate unique cultures and identities (Lionnet 2011; Braje et al. in press). Even today, isolation on islands attracts and promotes place identities of individuals and communities that differ from other areas (Camperio Ciani et al. 2007). Islanders tend to be identified as rugged, independent and stoic (Russell et al. in press). These identities are consolidated over generations living on islands and can even become genetically embedded (Camperio Ciani \& Capiluppi 2011). Just like endemic species, these endemic island cultures are vulnerable to IASs and the ensuing biotic homogenization (Tershy et al. 2015). Biological invasions can erode traditional ecological knowledge (Moller 2009) and drive people from their traditional lands, buildings and ways of life (Lee et al. 2015). They can be a threat to cultural monuments (e.g. the giant statues or 'moai' in Easter Island Rapa Nui) and to the cultural and natural integrity of United Nations Educational, Scientific and Cultural Organization (UNESCO) World Heritage Sites. However, some IASs that have been established for a long time can also adopt positive cultural value through their integration into cultures (Nuñez \& Simberloff 2005).

\section{DISTRIBUTION}

With the rapid increase in global trade over the past few centuries has come the concomitant increase in transportation of IASs (Westphal et al. 2008). IASs are now distributed across the planet and although only a subset of IASs are globally distributed, many more IASs are regionally and locally significant (Courchamp et al. 2017). Islands have tended to accumulate higher numbers of IASs per unit of land area (e.g. van Kleunen et al. 2015), which was historically interpreted as a vulnerability of islands to IAS colonization, in addition to their known vulnerability to IAS impacts (D'Antonio \& Dudley 1995). This colonization vulnerability has been ascribed to the impoverishment of native biota on islands (taxonomic disharmony, a lack of certain functional groups and 'vacant niches') and of evolution in long isolation from continental influences and pressures (e.g. strongly top-down predation, grazing mammals and diseases) not found on islands (Vitousek 1988). However, IASs have also been disproportionately introduced to islands ('propagule pressure') in an effort to enrich island biotas, and so islands may not be any more vulnerable to invasion than any other site (Jeschke \& Genovesi 2010). Thus, it is now generally considered that the greater number of IASs on islands per unit of area reflects higher propagule pressure to islands compared to continents (Denslow 2003). Although biological invasions of islands increase species richness relative to the extinctions caused by IASs and other threats, globally biological invasions are reducing biodiversity, as few species are introduced widely, while many more unique native species go extinct (Sax \& Gaines 2003).

\section{Small-island developing states}

Expert-verified lists of IASs on SIDSs are available from the Global Register of Introduced and Invasive Species (GRIIS) version 2.1. We use these data to analyse the occurrence, status and impact (sensu Latombe et al. in press) of terrestrial and aquatic IASs across four SIDS geographic regions comprising 33 self-governing, wholly island nations located in the Atlantic $(n=2)$, Caribbean $(n=13)$, Indian $(n=4)$ and Pacific $(n=14)$ regions. We exclude Bahrain in the Arabian Sea and Singapore in the South China Sea (sole geographical representatives in their region and connected to the mainland), along with continental (Belize, Guinea-Bissau, Guyana and Suriname) and sub-island (East Timor) SIDSs.

Our analysis excludes island territories and dependencies of continental nations that are not SIDSs (see also Keppel et al. 2012), and we caution that patterns of IAS introduction to and distribution on these islands with closer continental trade and governance links may differ (Costello et al. 2007). In the GRIIS, invasive species are defined as those that are known somewhere in the world to have impacts on biodiversity, ecosystems and the services they provide. We analyse records of all IASs in SIDSs regardless of whether impact has yet been observed on an island.

Across our 33 SIDSs, we documented 8668 presence records for 2034 potential IASs, comprising $76 \%$ plants, $23 \%$ animals and the remaining $1 \%$ fungi, chromists, viruses, bacteria and protozoa. Invaded environments were $83-88 \%$ terrestrial and $9-14 \%$ aquatic (variation arising from IASs present in both habitats), with the final 3\% being host specific. Evidence of invasiveness was documented for just over half $(53 \%)$ of these species on at least one SIDS (for the other half it was not specified rather than necessarily absent). For $5 \%$ of IAS records in SIDSs, the origin was unknown and the species classified as cryptogenic (i.e. potentially in native range).

\section{Patterns}

Just under half $(45 \%)$ of IASs were only recorded in one SIDS, and only 53 IASs (2.6\% of the IASs in SIDSs) were recorded in all four regions, a similar nested pattern others have found for IASs on tropical islands (Traveset et al. 2014). The prevalence of IASs in SIDSs differed significantly among regions, with IASs more likely to be present in multiple SIDSs in the Pacific Ocean (Fig. 1). The top 15 IASs, present in 26 or more SIDSs around the world, comprised a mix of plants, ants, rodents, a mosquito and a fish, and reflected that SIDSs exclusively fall in tropical regions (Table 1). Notably, plants make up over half $(60 \%)$ and are the only intentional introductions. Importantly, although these plants and ants are the most widely distributed, they are not necessarily the most damaging. This emphasizes the importance of ongoing vigilance and biosecurity to prevent the spread of other damaging IASs to islands, but perhaps also that the spread of the most damaging IASs has been purposefully limited. 
Table 1 Fifteen of the invasive alien species most globally prevalent on islands (source: Global Register of Introduced and Invasive Species). SIDS $=$ small-island developing state.

\begin{tabular}{|c|c|c|c|c|}
\hline Species & Name & Type & $S I D S s$ & Origin \\
\hline Leucaena leucocephala & White leadtree & Tree & 33 & Central America \\
\hline Casuarina equisetifolia & Ironwood & Tree & 32 & Southeast Asia to Australia \\
\hline Paratrechina longicornis & Longhorn crazy ant & Ant & 32 & Tropical Africa \\
\hline Rattus rattus & Black rat & Rodent & 31 & India to Southeast Asia \\
\hline Adenanthera pavonina & Red bead tree & Tree & 28 & India to South China \\
\hline Psidium guajava & Common guava & Tree & 28 & Central America \\
\hline Gliricidia sepium & Quick stick & Tree & 27 & Central America \\
\hline Kalanchoe pinnata & Air plant & Herb & 27 & Madagascar \\
\hline Tapinoma melanocephalum & Ghost ant & Ant & 27 & Tropical Africa and Asia \\
\hline Culex quinquefasciatus & Southern house mosquito & Mosquito & 26 & Tropical Americas \\
\hline Cyanthillium cinereum & Little ironweed & Herb & 26 & Tropical Africa and Asia \\
\hline Fatropha curcas & Barbados nut & Shrub & 26 & Central America \\
\hline Mus musculus & House mouse & Rodent & 26 & Central Asia \\
\hline Oreochromis mossambicus & Tilapia & Fish & 26 & Southern Africa \\
\hline Portulaca oleracea & Purslane & Herb & 26 & Africa and Asia \\
\hline
\end{tabular}

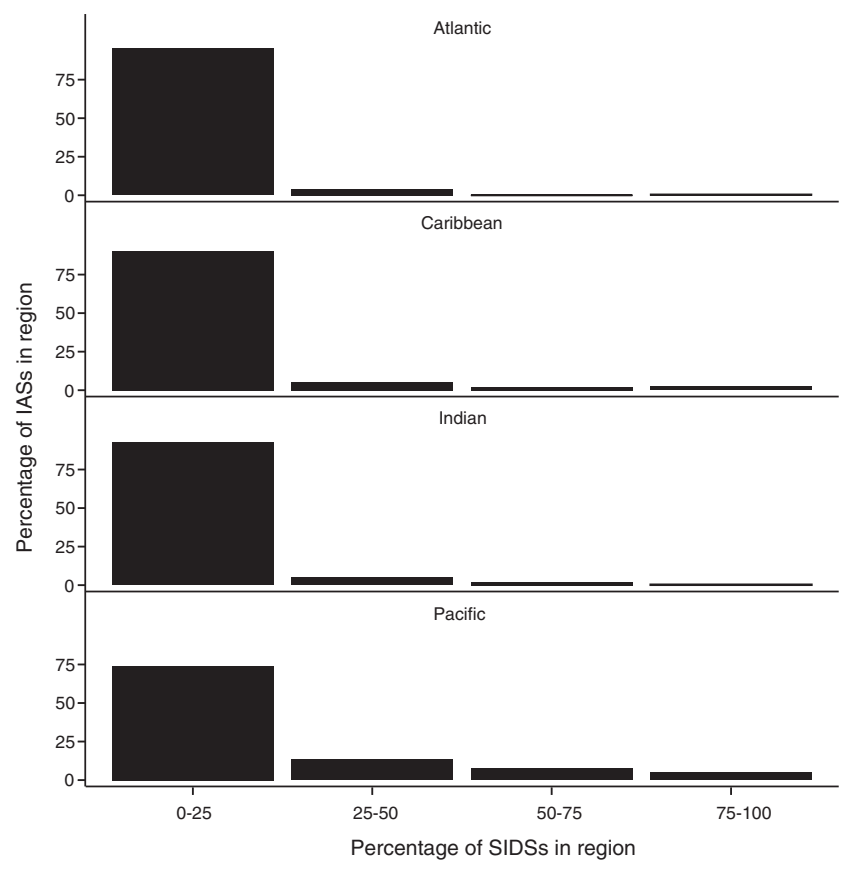

Figure 1 Percentage of IASs by percentage of SIDSs by region (source: Global Register of Introduced and Invasive Species).

IAS $=$ invasive alien species; SIDS = small-island developing state.

The SIDS with the most IASs was Cuba $(n=682)$, while that with the fewest was Sao Tome and Principe $(n=46)$, although we caution that the latter almost certainly reflects a lack of documentation effort. We investigated the relationship between IAS richness in SIDSs with their population size (median 197,541, range 1190-11,179,995), total land area (median $751 \mathrm{~km}^{2}$, range 21-462,840 $\mathrm{km}^{2}$ ) and coastline (median $403 \mathrm{~km}$, range $24-6112 \mathrm{~km}$ ), stratifying by region. All variables were $\log _{10}$ transformed to correct for rightskew. Population size, area and coastline of SIDSs are all tightly correlated, so we performed a linear regression of $\log _{10}$ IAS richness against the interaction of SIDS region and the

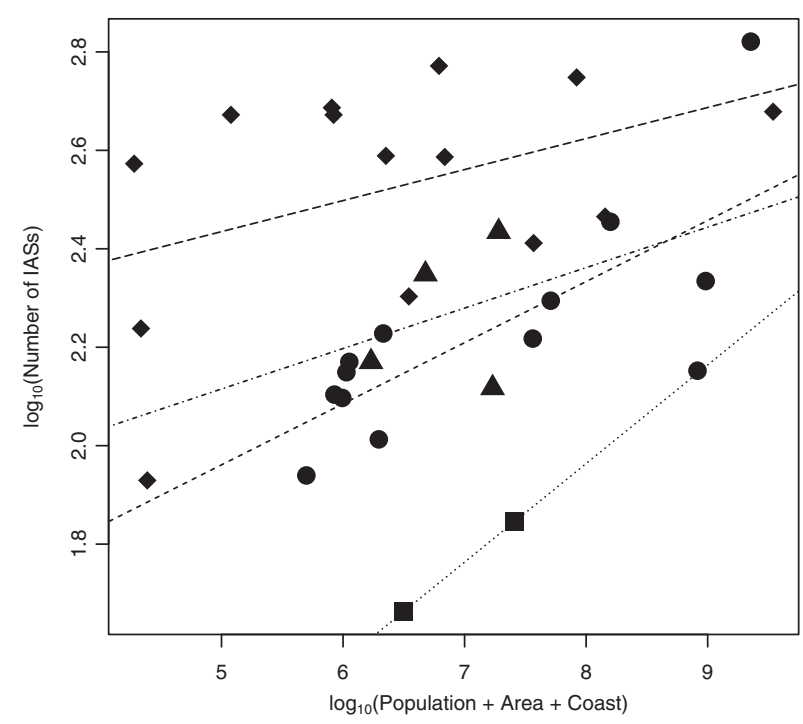

Figure 2 Number of IASs in small-island developing states against a principal component axis combining small-island developing state population size, area and coastline (source: worlddata.info). Regional lines of best fit are shown. Diamonds = Pacific Ocean; circles $=$ Caribbean Sea; triangles $=$ Indian Ocean; squares $=$ Atlantic Ocean. IAS $=$ invasive alien species.

absolute values of the first axis of a principal components analysis combining $\log _{10}$ values of all three variables. The first principal component captured $88 \%$ of the variability in SIDS population size, area and coastline. There was a strong positive relationship between IAS richness and the combination of SIDS population size, area and coastline $(p=0.006)$. Pacific Ocean SIDSs had significantly more IASs than other SIDS regions $(p=0.046)$, reflecting more IASs present at smaller SIDS sizes (Fig. 2). In the Pacific and Indian Oceans, SIDSs tended to have more IASs at smaller sizes but accumulated them more slowly, while in the Caribbean and the Atlantic Ocean, SIDSs tended to have fewer IASs at smaller sizes 
but accumulated them more rapidly (Fig. 2). We suspect that these trends reflect variability in the number of large islands within each SIDS, for which we do not have data. Analysis of the explanatory variables independently suggested that human population size had the stronger effect among them on IAS richness, as others have found for alien plant and bird species richness on islands (Blackburn et al. 2016), where trade and social rather than biogeographical factors have stronger impacts on IAS richness (van Kleunen et al. 2015).

\section{Indicators}

Patterns in IASs on islands over space and time should be quantified by indicators to allow robust assessment of trends and interventions (Latombe et al. in press). Trends in indicators of pressure (e.g. number of IASs), state (e.g. IAS impacts) and response (e.g. international agreements and national policy adoption) have all been applied to IASs (McGeoch et al. 2010). The number and accumulation of IASs (i.e. indicator pressure) in SIDSs in our analysis differed significantly by region. Other studies have shown that impacts of IASs (i.e. indicator state) are greater on islands than continents (Reaser et al. 2007), but at the same time eradications of IASs (i.e. indicator response) from islands create meaningful reversals in native species declines (Jones et al. 2016; Russell et al. 2016). Globally, the rate of alien species introductions has increased substantially over the past 200 years, and continues to do so, although with notable exceptions for mammals and fishes and in places such as New Zealand where stricter biosecurity is enforced (Seebens et al. 2017). However, globally consistent information is patchy for robust indicators on distribution (McGeoch et al. 2010) and impact (Bellard \& Jeschke 2016). Ultimately, better information for developing and monitoring indicators of IASs on islands will allow improved prioritization of IAS management on islands (McGeoch et al. 2016).

Invasion pathways comprise the vectors for transportation and the routes travelled (Essl et al. 2015). The pathways for IASs arriving at islands are a subset of those for IASs in general, where long-distance transportation by marine vessel and aircraft naturally dominates (Hulme 2009). This makes the dispersal of IASs to islands different in rate and type from both continents and natural colonizations (Wilson et al. 2016). Due to delays in reporting, new IASs on islands can take over a decade to enter records (Seebens et al. 2017), and an invasion debt is created by biological lag effects for IASs that have already arrived but are not yet established or expanded on islands (Essl et al. 2011). In the future, the vectors and pathways of IAS introduction to islands will continue to evolve (Hulme et al. 2008) and interact with other global change factors, such as climate change (Mainka \& Howard 2010).

\section{INTERACTIONS}

Globally across continents and islands, IASs rank highly as a threat to biodiversity (Maxwell et al. 2016). On islands alone,
IASs currently rank even higher as a threat to threatened (Bellard et al. 2016) and critically endangered species (Tershy et al. 2015), and were the greatest threat to extinct species (Tershy et al. 2015). However, compared to other threats, the collective impacts of IASs are often subtler, overlooked and harder to quantify and unambiguously assign (Courchamp et al. 2017), leading conservation managers to often focus on other threats, even if those are more intractable to solve. We discuss the interactions of IASs with the other global change threats identified by Maxwell et al. (2016).

\section{Over-exploitation}

Over-exploitation of species, through logging, hunting, fishing and plant gathering, continues to be the primary threat to biodiversity (Maxwell et al. 2016). Islands have a long history of over-exploitation (Atkinson et al. 2016), with Easter Island being a stark example of the ecological collapse that can follow (Brander \& Taylor 1998). IASs both interact with and benefit from over-exploitation of native species. On islands, over-harvesting of plants and animals by humans has been augmented by predation or herbivory by IASs, leading to rapid species extinctions (Cheke \& Hume 2008) and community regime shifts (Walker \& Meyers 2004). Subsequently, modified habitats then provide vacant niche opportunities and decreased resilience to further biological invasions (Shea \& Chesson 2002).

\section{Agricultural activity}

Agriculture on islands has always relied on the introduction of favoured non-native species. Many of these species that were introduced for agriculture have themselves gone on to become pests and IASs (Driscoll et al. 2014), and the agricultural pathway itself is a major vector for inadvertent new IAS introductions (e.g. hitchhikers). Agricultural intensification on islands has also led to widespread habitat clearance, which further encourages new invasions. Biocontrol has often been a preferred means for controlling IASs, historically for vertebrates and still today for plants and invertebrates (Messing \& Wright 2006). However, biocontrol should only be done if the consequences are extremely well understood (Simberloff 2006). IAS management on islands must therefore necessarily incorporate habitat management and restoration in order to rebuild resilience to invasion. Heterogeneous landscapes must also be strategically managed for IASs in order to minimize connectivity (Perry et al. in press) and promote native biodiversity across multiple land uses.

\section{Urban development}

The increasing trend towards urbanization focuses human activities into more densely populated areas. Whereas to some extent this mitigates habitat loss in more natural areas, it creates urban 'deserts', and urbanization typically impacts productive rural ecosystems (Martinuzzi et al. 2007). This 
inevitably reduces native species richness, and indeed all species richness in highly urbanized areas, but in suburban areas it increases introduced species richness (McKinney 2008). Densely populated cities have long been hubs for IAS transportation (Hulme 2009), and urbanized populations tend to associate nature firstly with introduced species (Shapiro et al. in press). Trade in pets and ornamental plants is focused around urban areas, which are source points for IASs into surrounding landscapes (Carrete \& Tella 2008; Hulme 2015), and air and sea ports of urban areas on islands are the primary entry points for IAS incursions.

\section{Climate change}

Although climate change ranks low among current threats to biodiversity (Maxwell et al. 2016), the magnitude of this threat is forecast to grow (Bellard et al. 2012), and islands will also be disproportionately vulnerable to the predicted impacts of climate change, such as sea level rise and coastal inundation (Mimura 1999). Predicting climate change impacts on islands is challenging, as larger-scale weather systems interact with island geography (Caujape-Castells et al. 2010). The threats of IASs and climate change are predicted generally to interact positively (Bellard et al. 2013). Five consequence of climate change for invasive species include: (1) altered transport and introduction mechanisms; (2) establishment of new invasive species; (3) altered impact of existing invasive species; (4) altered distribution of existing invasive species; and (5) altered effectiveness of control strategies (Hellmann et al. 2008). IASs are adaptable colonists with a broader range of tolerances to environmental variation and disturbance, and although climate change may not alter the rate of IAS introduction, it is likely to improve establishment rates (Hulme in press). Climate change resilience and IAS management should be considered simultaneously in island conservation planning (Courchamp et al. 2014); however, because island nations have very little control over global climate change, it may be most worthwhile then investing in IAS mitigation through control and eradication programmes (Jones et al. 2016), which will generate additional resilience in native species populations and ecosystems to climate change threats.

\section{Community engagement}

As we demonstrated for SIDSs, the number of IASs on islands is directly correlated with island area and human population size (Kueffer et al. 2010, Blackburn et al. 2016). Even on uninhabited islands, IASs originated from human agency, and their management depends on human intervention. The management of IASs on islands, or indeed anywhere, must therefore be considered as part of a broader exercise of engagement within a coupled socio-ecological system (Crowley et al. 2017; Schmitz et al. in press). Conflicts of interest can arise in IAS management when species that are considered invasive by one sector of society are considered a resource by another (Russell 2014). Important examples include game animals, pets and ornamental plants. Where appropriate recourse is not given to managing such conflicts, broader opposition to IAS management can occur because of opposition to methods, sensitivity around species with domestic analogues and low awareness of impacts (Witmer \& Fuller 2011). People living on islands tend to have tighter-knit communities and senses of identity, and IAS management must take into account their broader values and, in particular, an inclusive approach to IAS decision-making and management (Russell et al. in press). Ultimately, these social aspects determine whether eradication of an IAS in an island is an option and which methods are acceptable (Oppel et al. 2011; Glen et al. 2013).

\section{MANAGEMENT}

Biological invasions occur along a series of stages (Blackburn et al. 2011; though see also Colautti \& MacIssac 2004), and at each stage the suite of available management responses in order to mitigate, reduce or eliminate IAS impacts differs. Costs and opportunities for managing IASs increase rapidly as invasion progresses. Because of their clearly demarcated borders and limited areas, management responses to IASs can be more decisive on islands (Simberloff 2001). Managers must have processes: to prevent IAS arrival with biosecurity, to manage the urgency associated with recent colonists and early eradication, for ongoing adaptive management, and for control strategies. The two most important objectives at any stage of an invasion are likely to be reducing population size and 'rolling back' the distribution of the invader.

\section{Biosecurity}

Prevention of biological invasions is by far the most costeffective management strategy (Leung et al. 2002; Timmins \& Braithwaite 2002; Hulme 2006). Biosecurity comprises the strategy, efforts and planning to minimize the likelihood of invasive species transport, arrival or establishment (Meyerson \& Reaser 2002, 2003). Optimal biosecurity and surveillance must consider the relative risks and the financial costs of differing strategies in order to implement the optimal biosecurity strategy (Hauser \& McCarthy 2009; Rout et al. 2011). Biosecurity initiatives are generally classified as quarantine, surveillance and response actions. Quarantine involves isolation of propagules and potential vectors at specified locations to facilitate screening and treatment, and may occur at departure points, during transport or following arrival at an island. Surveillance consists of the actions taken to monitor for propagules during transport and following arrival, both within and outside of quarantine. Once there is a quarantine breach or surveillance detection, a contingency response is launched. A contingency response is a calculated exercise to eliminate the incursion. It must be made immediately and with the same intensity as an eradication campaign. Before an incursion actually occurs, it is important that the capacity and planning for a contingency response are 


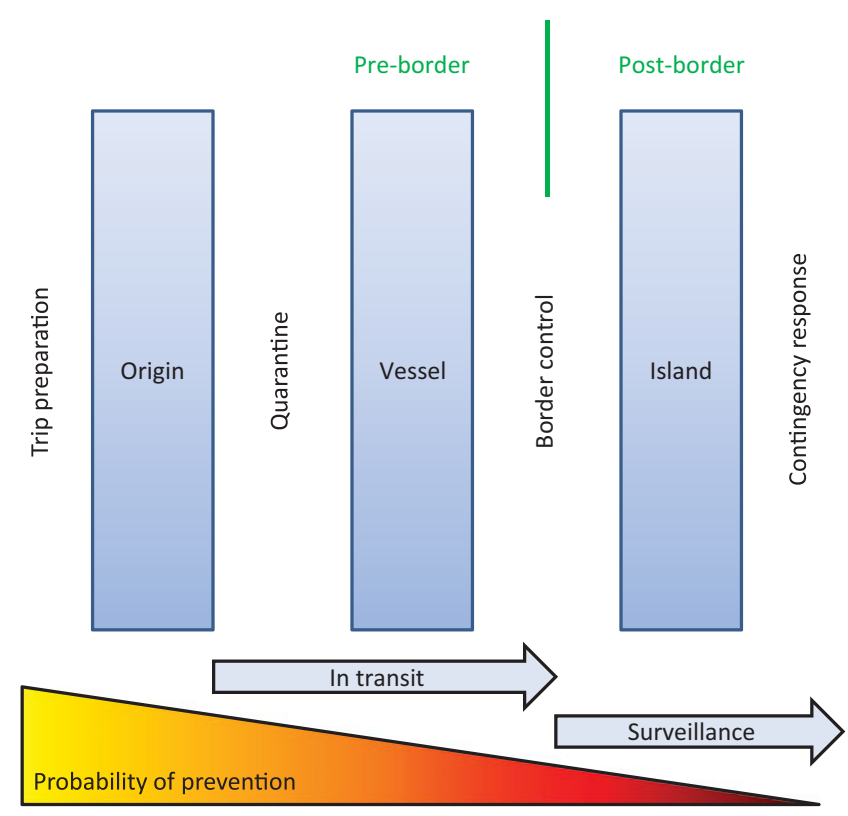

Figure 3 Biosecurity for intercepting invasive alien species on islands (modified with permission from Broome 2007, following Blackburn et al. 2011).

established. In all cases biosecurity is an ongoing action with associated costs in the face of unrelenting propagule pressure.

Biosecurity is particularly important on islands where although the probability of an invasion occurring can be quite low, the conservation value is greatest and so the consequences of any such invasion can be comparatively great. Uninvaded islands typically have the highest conservation value and should always be a priority for IAS management. Islands predispose themselves to successful biosecurity as they typically have fewer entry points (e.g. air and sea ports) through which all traffic must pass. Island biosecurity historically focused on protecting agricultural values, but the same processes have readily been adapted to protecting biodiversity values. Successful biosecurity also requires appropriate consideration of policies, governance and broader economics (Cook et al. 2010; Heikkilä 2011; Richardson 2011). The interaction between biosecurity initiatives and the invasion process can be conceptually represented (Fig. 3). The earlier in the invasion process that a propagule is intercepted, the greater the probability of invasion prevention, often at a reduced cost.

\section{Control}

For most IASs, once they have become established on an island (i.e. are self-sustaining and breeding), elimination is no longer feasible and management must move towards control and mitigation (Rejmánek \& Pitcairn 2002). Plants, invertebrates and vertebrates have all been eradicated as incursions during the establishment phase of biological invasions (Glen et al. 2013). If eradication of the species is possible, it is most likely to be successful at this time, and for some taxa such as insects, eradication is generally only possible during this phase (Liebhold et al. 2016). Reducing the population size of an IAS during establishment increases the likelihood of it falling below Allee thresholds, thereby facilitating eradication by preventing secure establishment (Leibhold \& Bascompte 2003).

Significant IAS management can take place at the subisland level at intensively managed sites, particularly where local suppression to zero density may be achieved (we reserve the term 'eradication' for an island-wide removal programme following IAS establishment). Such sites are important for protecting values until such time as island-wide eradication becomes feasible, and management strategies at these sites can mimic those for entire islands (e.g. 'mainland islands' in New Zealand; Saunders \& Norton 2001). IAS management on islands typically relies on a few standard taxa-specific methods, such as manual, mechanical, chemical and biological control (Rocamora \& Henrietta 2016). Classical biological control, by introducing host-specific natural enemies, constitutes both a control option, especially for widespread invasive plants and arthropods, and a tool to partially restore invaded natural systems (Van Driesche et al. 2016). However, the development of new control tools, particularly advances in synthetic biology (Piaggio et al. 2017), may create novel opportunities for IAS control and eradications (Campbell et al. 2015).

\section{Eradication}

Eradication is best attempted when the population growth rate is low (i.e. the invasion curve is flat). Eradication is therefore likely to be most successful either early in the invasion, just following arrival, or else once the population has stabilized at a local carrying capacity. However, any reduction in population size at carrying capacity will prompt an increase in the population growth rate. Six criteria are considered necessary for eradication: (1) removal exceeds rate of increase at all densities; (2) immigration is prevented; (3) all reproductive individuals can be put at risk by the eradication technique; (4) individuals can be detected at low densities; (5) the benefits of the project outweigh the costs; and (6) the project is sociopolitically acceptable (Bomford \& O'Brien 1995). Eradication at carrying capacity must therefore be a decisive action, and is unlikely to be achieved as an outcome of ongoing control, and thus we treat it differently from control at carrying capacity (Bomford \& O'Brien 1995). Eradication at any stage may be possible, given sufficient investment to ensure that the rate of removal greatly exceeds the population growth rate, and preferably should occur as early as possible in the invasion pathway, where success rates are typically higher and overall costs lower (Rejmánek \& Pitcairn 2002; Glen et al. 2013). However, eradication of invasive vascular plants is always challenging when they have long-lasting seedbanks (Meyer 2014; Panetta 2015).

Permanent eradication of IASs is often more cost effective (Pascal et al. 2008) and ethical (Russell et al. 2016) than 


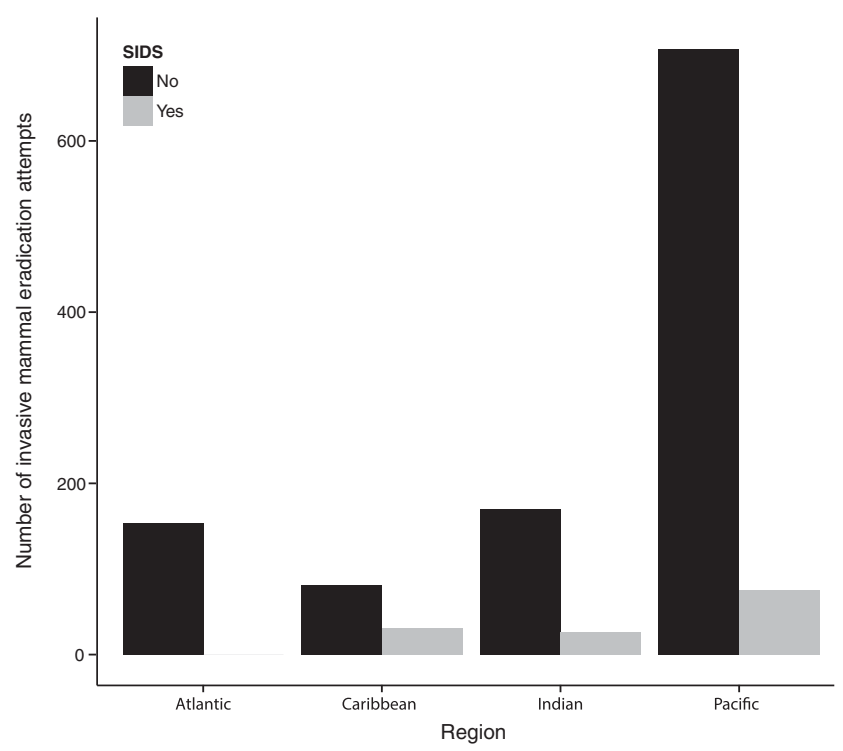

Figure 4 Invasive mammal eradication attempts (including successful, successful but reinvaded, failed, in progress or to be confirmed) comparing SIDSs to all other islands, where events are classified as good or satisfactory data quality and the whole island was treated. Data accessed February 2017 (source: Database of Island Invasive Species Eradications). SIDS $=$ small-island developing state.

control over very long time horizons. However, the number of IAS taxa for which island-wide eradication is currently possible is limited. Eradication feasibility is currently high for invasive mammals on islands with sizes on the scale of thousands to tens of thousands of hectares, and can be achieved at carrying capacity. Mammal eradications have focused on the most widespread species including invasive rodents (Howald et al. 2007), feral cats (Campbell et al. 2011) and ungulates (Campbell \& Donlan 2005). From the Database of Island Invasive Species Eradications (DIISE), over 1200 eradication attempts have been made on over 800 islands worldwide, with a success rate of $c .85 \%$. The majority of these eradication attempts $(60 \%)$ have been in the Pacific Ocean (with half of these being in New Zealand), but only $10 \%$ have been in SIDSs (Fig. 4). This bias reflects the history of expertise in invasive mammal eradications (Russell \& Broome 2016), the resources required for wholeisland invasive mammal eradication (Russell \& Holmes 2015) and the role that greater inhabitation on SIDSs plays in eradication feasibility (Oppel et al. 2011). Greater investment in IAS eradication from SIDSs is warranted alongside other conservation interventions (Dahl in press).

In comparison, invasive bird eradication feasibility is currently limited to islands with sizes on the scale of hundreds of hectares for volant birds, but is only limited to islands with sizes of tens of thousands of hectares for non-volant birds. For reptiles and amphibians, only early interception has proved successful (Kraus 2009). Plant eradications are almost entirely restricted to the sub-island level, with sizes on the scale of tens to hundreds of hectares (Rejmánek \& Pitcairn 2002), and as for animal eradications depend on the attributes of the target species (Panetta 2015), require a strong commitment to completion (Buddenhagen \& Tye 2015) and where once again early interception is critical (Mack \& Lonsdale 2002). Invasive invertebrate eradication feasibility varies greatly depending on the biology of the taxa involved and the tools available. Arthropods have been successfully eradicated over areas at the scale of tens of thousands of hectares (Tobin et al. 2014), and with new technique developments (Boser et al. in press), some advances have recently been made for eradicating invasive ants in areas at the scale of tens of hectares (Hoffman et al. 2016), but for other insects there remains an urgency to discover and develop appropriate tools for any reliable detection and control, let alone eradication (Brockerhoff et al. 2010).

\section{CONCLUSIONS}

IASs are disproportionately prevalent on islands, where they also generate disproportionate impacts compared to continental areas. They have played a major role in structuring modern ecological communities on islands. The impacts of IASs on islands are forecast to only increase with time, and today and for the foreseeable future, IASs are likely to be the strongest drivers of plant and animal population declines and extinctions on islands, but the identification and scope of IAS impacts on islands should be broadened to include nonbiodiversity impacts. Indicators for IASs on islands, including their occurrence, status and impact, should all be collected and monitored over time. Conceptualizing the biological invasion process in a population biology framework better equips managers to respond to IASs on islands, including implementing successful biosecurity, control and eradication interventions. The impact and distribution of IASs on islands will continue to grow and interact with other global change threats, and climate change is likely to have particularly pernicious impacts on the biodiversity impacts of IASs. Because inhabited islands are tightly coupled socio-ecological systems, more work is required in order to understand how to work with island communities on IAS management, and stronger collaborations among island countries and territories may contribute to that effort.

\section{ACKNOWLEDGEMENTS}

Thanks to the editor Nick Polunin for inviting this contribution to the special issue and his patience and proof-reading during its preparation. Thanks to Steffen Oppel and two anonymous reviewers for their positive and thorough comments. James Russell was funded by Rutherford Discovery Fellowship grant RDF-UOA1404. The Global Register of Introduced and Invasive Species (GRIIS) has been developed with co-funding from the European Union through the Secretariat of the Convention on Biological Diversity (CBD) within the framework of the Global Invasive Alien Species Information Partnership (GIASIP). The GIASIP 
has come together to assist Parties to the $\mathrm{CBD}$, and others, implement Article 8(h) and Target 9 of the Aichi Biodiversity Targets: "By 2020, invasive alien species and pathways are identified and prioritized, priority species are controlled and eradicated, and measures are in place to manage pathways to prevent introduction and establishment."

\section{References}

Abernethy, E.F., Turner, K.L., Beasley, J.C., DeVault, T.L., Pitt, W.C. \& Rhodes, O.E. (2016) Carcasses of invasive species are predominantly utilized by invasive scavengers in an island ecosystem. Ecosphere 7: e01496.

Atkinson, Q.D., Coomber, T., Passmore, S., Greenhill, S.J. \& Kushnick, G. (2016) Cultural and environmental predictors of pre-european deforestation on Pacific Islands. PLoS ONE 11: e0156340.

Bartz, R., Heink, U. \& Kowarik, I. (2010) Proposed definition of environmental damage illustrated by the cases of genetically modified crops and invasive species. Conservation Biology 24: 675681.

Beever, R.E., Waipara, N.W., Ramsfield, T.D., Dick, M.A. \& Horner, I.J. (2009) Kauri (Agathis australis) under threat from Phytophthora. In: Phytophthoras in Forests and Natural Ecosystems, eds. E.M. Goheen, \& S.J. Frankel, pp. 74-85. Albany, CA, USA: USDA/Forest Service, Pacific Southwest Research Station.

Bellard, C., Bertelsmeier, C., Leadley, P., Thuiller, W. \& Courchamp, F. (2012) Impacts of climate change on the future of biodiversity. Ecology Letters 15: 365-377.

Bellard, C., Cassey, P. \& Blackburn, T.M. (2016) Alien species as a driver of recent extinctions. Biology Letters 12: 20150623.

Bellard, C. \& Jeschke, J.M. (2016) A spatial mismatch between invader impacts and research publications. Conservation Biology 30: 230-232.

Bellard, C., Thuiller, W., Leroy, B., Genovesi, P., Bakkenes, M. \& Courchamp, F. (2013) Will climate change promote future invasions? Global Change Biology 19: 3740-3748.

Blackburn, T.M., Pyšek, P., Bacher, S., Carlton, J.T., Duncan, R.P., et al. (2011) A proposed unified framework for biological invasions. Trends in Ecology E Evolution 26: 333-339.

Blackburn, T.M., Delean, S., Pyšek, P. \& Cassey, P. (2016) On the island biogeography of aliens: a global analysis of the richness of plant and bird species on oceanic islands. Global Ecology and Biogeography 25: 859-868.

Bomford, M. \& O'Brien, P. (1995) Eradication or control for vertebrate pests? Wildlife Society Bulletin 23: 249-255.

Boser, C.L., Hanna, C., Holway, D.A., Faulkner, K.R., Naughton, I., et al. (in press) Protocols for Argentine ant eradication in conservation areas. Fournal of Applied Entomology.

Bradshaw, C.J., Leroy, B., Bellard, C., Roiz, D., Albert, C., et al. (2016) Massive yet grossly underestimated global costs of invasive insects. Nature Communications 7: 12986.

Braje, T.J., Leppard, T.P., Fitzpatrick, S.M., \& Erlandson, J.M. (in press) Archaeology, historical ecology and anthropogenic island ecosystems. Environmental Conservation.

Brander, J.A. \& Taylor, M.S. (1998) The simple economics of Easter Island: a Ricardo-Malthus model of renewable resource use. American Economic Reviem 88: 119-138.

Briguglio, L. (1995) Small island developing states and their economic vulnerabilities. World Development 23: 1615-1632.
Brockerhoff, E.G., Liebhold, A.M., Richardson, B. \& Suckling, D.M. (2010) Eradication of invasive forest insects: concepts, methods, costs and benefits. Nem Zealand Fournal of Forestry Science 40: S117-S135.

Broome, K. (2007) Island biosecurity as a pest management tactic in New Zealand. In: Managing Vertebrate Invasive Species, eds. G.W. Witmer, W.C. Pitt \& K.A. Fagerstone, pp. 104-107. Fort Collins, CO, USA: USDA/APHIS Wildlife Services, National Wildlife Research Center.

Buddenhagen, C. \& Tye, A. (2015) Lessons from successful plant eradications in Galapagos: commitment is crucial. Biological Invasions 17: 2893-2912.

Bunce, M., Mee, L., Rodwell, L.D. \& Gibb, R. (2009) Collapse and recovery in a remote small island - a tale of adaptive cycles or downward spirals? Global Environmental Change 19: 213-226.

Campbell, K.J., Beek, J., Eason, C.T., Glen, A.S., Godwin, J., et al. (2015) The next generation of rodent eradications: innovative technologies and tools to improve species specificity and increase their feasibility on islands. Biological Conservation 185: 47-58.

Campbell, K. \& Donlan, C. (2005) Feral goat eradications on islands. Conservation Biology 19: 1362-1374.

Campbell, K.J., Harper, G., Algar, D., Hanson, C.C., Keitt, B.S. \& Robinson, S. (2011) Review of feral cat eradications on islands. In: Island Invasives: Eradication and Management, eds. C.R. Veitch, M.N. Clout \& D.R. Towns, pp, 37-46. Gland, Switzerland: IUCN.

Camperio Ciani, A. \& Capiluppi, C. (2011) Gene flow by selective emigration as a possible cause for personality differences between small islands and mainland populations. European Fournal of Personality 25: 53-64.

Camperio Ciani, A.S., Capiluppi, C., Veronese, A. \& Sartori, G. (2007) The adaptive value of personality differences revealed by small island population dynamics. European Fournal of Personality 21: 3-22.

Carrete, M. \& Tella, J. (2008) Wild-bird trade and exotic invasions: a new link of conservation concern? Frontiers in Ecology and the Environment 6: 207-211.

Caujape-Castells, J., Tye, A., Crawford, D.J., Santos-Guerra, A., Sakai, A., et al. (2010) Conservation of oceanic island floras: present and future global challenges. Perspectives in Plant Ecology, Evolution and Systematics 12: 107-129.

Cheke, A.S. \& Hume, J.P. (2008) Lost Land of the Dodo: The Ecological History of the Mascarene Islands. London, UK: T. \& A. D. Poyser.

Colautti, R.I. \& MacIsaac, H.J. (2004) A neutral terminology to define 'invasive' species. Diversity and Distributions 10: 135-141.

Cook, D.C., Liu, S., Murphy, B. \& Lonsdale, W.M. (2010) Adaptive approaches to biosecurity governance. Risk Analysis 30: 13031314.

Costello, C., Springborn, M., McAusland, C. \& Solow, A. (2007) Unintended biological invasions: does risk vary by trading partner? Journal of Environmental Economics and Management 54: 262-276.

Courchamp, F., Chapuis, J.-L. \& Pascal, M. (2003) Mammal invaders on islands: impact, control and control impact. Biological Reviems 78: 347-383.

Courchamp, F., Fournier, A., Bellard, C., Bertelsmeier, C., Bonnaud, E., Jeschke, J.M. \& Russell, J.C. (2017) Invasion biology: specific problems and possible solutions. Trends in Ecology $\mathcal{E}$ Evolution 32: 13-22.

Courchamp, F., Hoffmann, B.D., Russell, J.C., Leclerc, C. \& Bellard, C. (2014) Climate change, sea-level rise, and conservation: 
keeping island biodiversity afloat. Trends in Ecology E Evolution 29: 127-130.

Crowley, S.L., Hinchliffe, S. \& McDonald, R.A. (2017) Invasive species management will benefit from social impact assessment. Journal of Applied Ecology, 54: 351-357.

Crump, J.A., Murdoch, D.R. \& Baker, M.G. (2001) Emerging infectious diseases in an island ecosystem: the New Zealand perspective. Emerging Infectious Diseases 7: 767-772.

Cushman, J.H. (1995) Ecosystem-level consequences of species additions and deletions on islands. In: Islands: Biological Diversity and Ecosystem Function, eds. P.M. Vitousek, L.L. Loope \& H. Adsersen, pp. 135-147. New York, NY, USA: SpringerVerlag.

D’Antonio, C.M. \& Dudley, T.L. (1995) Biological invasions as agents of change on islands versus mainlands. In: Islands: Biological Diversity and Ecosystem Function, eds. P.M. Vitousek, L.L. Loope \& H. Adsersen, pp. 103-121. New York, NY, USA: SpringerVerlag.

Dahl, A.L. (in press) Island conservation issues in international conventions and agreements. Environmental Conservation.

Daszak, P., Cunningham, A.A. \& Hyatt, A.D. (2000) Emerging infectious diseases of wildlife - threats to biodiversity and human health. Science 287: 443-449.

de Wit, L.A., Croll, D.A., Tershy, B., Newton, K.M., Spatz, D., et al. (2017) Estimating burdens of neglected tropical zoonotic diseases on islands with introduced mammals. The American Fournal of Tropical Medicine and Hygiene 96: 749757.

Delgado, J., Riera, R., Rodríguez, R., González-Moreno, P. \& Fernández-Palacios, J. (in press) A reappraisal of the role of humans in the biotic disturbance of islands. Environmental Conservation.

Denslow, J.S. (2003) Weeds in paradise: thoughts on the invasibility of tropical islands. Annals of the Missouri Botanical Garden 90: 119-127.

Downey, P.O. \& Richardson, D.M. (2016) Alien plant invasions and native plant extinctions: a six-threshold framework. AoB Plants 8 : plw047.

Driscoll, D.A., Catford, J.A., Barney, J.N., Hulme, P.E., Martin, T.G., et al. (2014) New pasture plants intensify invasive species risk. Proceedings of the National Academy of Sciences of the United States of America 111: 16622-16627.

Essl, F., Bacher, S., Blackburn, T.M., Booy, O., Brundu, G., et al. (2015) Crossing frontiers in tackling pathways of biological invasions. BioScience 65: 769-782.

Essl, F., Dullinger, S., Rabitsch, W., Hulme, P.E., Hülber, K., et al. (2011) Socioeconomic legacy yields an invasion debt. Proceedings of the National Academy of Sciences of the United States of America 108: 203-207.

Fukami, T., Wardle, D.A., Bellingham, P.J., Mulder, C.P., Towns, D.R., et al. (2006) Above-and below-ground impacts of introduced predators in seabird-dominated island ecosystems. Ecology Letters 9: 1299-1307.

Glen, A.S., Atkinson, R., Campbell, K.J., Hagen, E., Holmes, N.D., et al. (2013) Eradicating multiple invasive species on inhabited islands: the next big step in island restoration? Biological Invasions 15: 2589-2603.

Hauser, C.E. \& McCarthy, M.A. (2009) Streamlining 'search and destroy': cost-effective surveillance for invasive species management. Ecology Letters 12: 683-692.
Heikkilä, J. (2011) Economics of biosecurity across levels of decisionmaking: a review. Agronomy for Sustainable Development 31: 119138.

Hellmann, J.J., Byers, J.E., Bierwagen, B.G. \& Dukes, J.S. (2008) Five potential consequences of climate change for invasive species. Conservation Biology 22: 534-543.

Hoffmann, B.D., Luque, G.M., Bellard, C., Holmes, N.D. \& Donlan, C.J. (2016) Improving invasive ant eradication as a conservation tool: a review. Biological Conservation 198: 37-49.

Howald, G., Donlan, C., Galván, J.P., Russell, J.C., Parkes, J., et al. (2007) Invasive rodent eradication on islands. Conservation Biology 21: $1258-1268$.

Hulme, P.E. (2006) Beyond control: wider implications for the management of biological invasions. Fournal of Applied Ecology 43: 835-847.

Hulme, P.E. (2009) Trade, transport and trouble: managing invasive species pathways in an era of globalization. Fournal of Applied Ecology 46: 10-18.

Hulme, P.E. (2011) Addressing the threat to biodiversity from botanic gardens. Trends in Ecology E Evolution 26: 168-174.

Hulme, P.E. (2015) Invasion pathways at a crossroad: policy and research challenges for managing alien species introductions. Fournal of Applied Ecology 52: 1418-1424.

Hulme, P.E. (in press) Climate change and biological invasions: evidence, expectations, and response options. Biological Reviems.

Hulme, P.E., Bacher, S., Kenis, M., Klotz, S., Kühn, I., et al. (2008) Grasping at the routes of biological invasions: a framework for integrating pathways into policy. Fournal of Applied Ecology 45: 403-414.

Jay, M., Morad, M. \& Bell, A. (2003) Biosecurity, a policy dilemma for New Zealand. Land Use Policy 20: 121-129.

Jeschke, J.M., Bacher, S., Blackburn, T.M., Dick, J.T., Essl, F., et al. (2014) Defining the impact of non-native species. Conservation Biology 28: 1188-1194.

Jeschke, J.M. \& Genovesi, P. (2010) Do biodiversity and human impact influence the introduction or establishment of alien mammals? Oikos 120: 57-64.

Jones, H.P., Holmes, N.D., Butchart, S.H., Tershy, B.R., Kappes, P.J., et al. (2016) Invasive mammal eradication on islands results in substantial conservation gains. Proceedings of the National Academy of Sciences of the United States of America 113: 4033-4038.

Keppel, G., Morrison, C., Watling, D., Tuiwawa, M.V. \& Rounds, I.A. (2012) Conservation in tropical Pacific Island countries: why most current approaches are failing. Conservation Letters 5: 256265.

Kraus, F. (2009) Alien Reptiles and Amphibians: A Scientific Compendium and Analysis. Dordrecht, The Netherlands: Springer.

Kriticos, D.J., Phillips, C.B. \& Suckling, D.M. (2005) Improving border biosecurity: potential economic benefits to New Zealand. Nem Zealand Plant Protection 58: 1-6.

Kueffer, C., Daehler, C.C., Torres-Santana, C.W., Lavergne, C., Meyer, J.Y., et al. (2010) A global comparison of plant invasions on oceanic islands. Perspectives in Plant Ecology, Evolution and Systematics 12: 145-161.

Latombe, G., Pyšek, P., Jeschke, J.M., Blackburn, T.M., Bacher, $\mathrm{S}$., et al. (in press) A vision for global monitoring of biological invasions. Biological Conservation.

Lee, D.J., Motoki, M., Vanderwoude, C., Nakamoto, S.T. \& Leung, P. (2015) Taking the sting out of Little Fire Ant in Hawaii. Ecological Economics 111: 100-110. 
Leung, B., Lodge, D.M., Finnoff, D., Shogren, J.F., Lewis, M.A. \& Lamberti, G. (2002) An ounce of prevention or a pound of cure: bioeconomic risk analysis of invasive species. Proceedings of the Royal Society of London B 269: 2407-2413.

Liebhold, A. \& Bascompte, J. (2003) The Allee effect, stochastic dynamics and the eradication of alien species. Ecology Letters 6 : 133-140.

Liebhold, A.M., Berec, L., Brockerhoff, E.G., Epanchin-Niell, R.S., Hastings, A., et al. (2016) Eradication of invading insect populations: from concepts to applications. Annual Reviem of Entomology 61: 335-352.

Lionnet, F. (2011) Cosmopolitan or Creole lives? Globalized oceans and insular identities. Profession 2011: 23-43.

Losos, J.B. \& Ricklefs, R.E. (2009) Adaptation and diversification on islands. Nature 457: 830-836.

Mack, R.N. \& Lonsdale, W.M. (2002) Eradicating invasive plants: hard-won lessons for islands. In: Turning the Tide: The Eradication of Invasive Species, eds. C.R. Veitch \& M.N. Clout, pp. 164-172. Gland, Switzerland and Cambridge, UK: IUCN SSC Invasive Species Specialist Group, IUCN.

Mainka, S.A. \& Howard, G.W. (2010) Climate change and invasive species: double jeopardy. Integrative Zoology 5: 102-111.

Martinuzzi, S., Gould, W.A. \& Gonzalez, O.M.R. (2007) Land development, land use, and urban sprawl in Puerto Rico integrating remote sensing and population census data. Landscape and Urban Planning 79: 288-297.

Maxwell, S.L., Fuller, R.A., Brooks, T.M. \& Watson, J.E. (2016) Biodiversity: the ravages of guns, nets and bulldozers. Nature 536: 143-145

Mazza, G., Tricarico, E., Genovesi, P. \& Gherardi, F. (2014) Biological invaders are threats to human health: an overview. Ethology Ecology E Evolution 26: 112-129.

McCreless, E.E., Huff, D.D., Croll, D.A., Tershy, B.R., Spatz, D.R., et al. (2016) Past and estimated future impact of invasive alien mammals on insular threatened vertebrate populations. Nature Communications 7: 12488

McGeoch, M.A., Butchart, S.H., Spear, D., Marais, E., Kleynhans, E.J., et al. (2010) Global indicators of biological invasion: species numbers, biodiversity impact and policy responses. Diversity and Distributions 16: 95-108.

McGeoch, M.A., Genovesi, P., Bellingham, P.J., Costello, M.J., McGrannachan, C. \& Sheppard, A. (2016) Prioritizing species, pathways, and sites to achieve conservation targets for biological invasion. Biological Invasions 18: 299-314.

McKinney, M.L. (2008) Effects of urbanization on species richness: a review of plants and animals. Urban Ecosystems 11: 161-176.

Messing, R.H. \& Wright, M.G. (2006) Biological control of invasive species: solution or pollution? Frontiers in Ecology and the Environment 4: 132-140.

Meyer, J.Y. (2014) Critical issues and new challenges for research and management of invasive plants in the Pacific Islands. Pacific Conservation Biology 20: 146-164.

Meyerson, L.A. \& Reaser, J.K. (2002) Biosecurity: moving toward a comprehensive approach. BioScience 52: 593-600.

Meyerson, L.A. \& Reaser, J.K. (2003) Bioinvasions, bioterrorism, and biosecurity. Frontiers in Ecology and the Environment 1: 307314.

Mimura, N. (1999) Vulnerability of island countries in the South Pacific to sea level rise and climate change. Climate Research 12: 137-143.
Moller, H. (2009) Matauranga Maori, science and seabirds in New Zealand. Nem Zealand Fournal of Zoology 36: 203-210.

Mwebaze, P., MacLeod, A., Tomlinson, D., Barois, H. \& Rijpma, J. (2010) Economic valuation of the influence of invasive alien species on the economy of the Seychelles islands. Ecological Economics 69: 2614-2623.

Nuñez, M.A. \& Simberloff, D. (2005) Invasive species and the cultural keystone species concept. Ecology and Society 10: r4.

Oppel, S., Beaven, B.M., Bolton, M., Vickery, J. \& Bodey, T.W. (2011) Eradication of invasive mammals on islands inhabited by humans and domestic animals. Conservation Biology 25: 232240.

Panetta, F.D. (2015) Weed eradication feasibility: lessons of the 21st century. Weed Research 55: 226-238.

Pascal, M., Lorvelec, O., Bretagnolle, V. \& Culioli, J.M. (2008) Improving the breeding success of a colonial seabird: a cost-benefit comparison of the eradication and control of its rat predator. Endangered Species Research 4: 267-276.

Pelling, M. \& Uitto, J.I. (2001) Small island developing states: natural disaster vulnerability and global change. Global Environmental Change Part B: Environmental Hazards 3: 49-62.

Perry, G.L., Moloney, K.A. \& Etherington, T.R. (in press) Using network connectivity to prioritise sites for the control of invasive species. Fournal of Applied Ecology.

Piaggio, A.J., Segelbacher, G., Seddon, P.J., Alphey, L., Bennett, E.L., et al. (2017) Is it time for synthetic biodiversity conservation? Trends in Ecology E Evolution 32: 97-107.

Pimentel, D., Zuniga, R. \& Morrison, D. (2005) Update on the environmental and economic costs associated with alien-invasive species in the United States. Ecological Economics 52: 273-288.

Reaser, J.K., Meyerson, L.A., Cronk, Q., De Poorter, M., Eldrege, L.G., et al. (2007) Ecological and socioeconomic impacts of invasive alien species in island ecosystems. Environmental Conservation 34: 98-111.

Rejmánek, M. \& Pitcairn, M.J. (2002) When is eradication of exotic pest plants a realistic goal? In: Turning the Tide: The Eradication of Invasive Species, eds. C.R. Veitch \& M.N. Clout, pp. 249-253. Gland, Switzerland and Cambridge, UK: IUCN SSC Invasive Species Specialist Group, IUCN.

Richardson, D.M. (2011) Invasion science: the roads travelled and the roads ahead. In: Fifty Years of Invasion Ecology: The Legacy of Charles Elton, ed. D.M. Richardson, pp. 397-407. Chichester, UK: Blackwell Publishing Ltd.

Rocamora, G. \& Henriette, E. (2016) Invasive Alien Species in Seychelles: Why and How to Eliminate Them. Identification and Management of Priority Species. Paris, France: Biotope Éditions, Mèze, Muséum National d'Histoire Naturelle.

Roemer, G.W., Donlan, C.J. \& Courchamp, F. (2002) Golden eagles, feral pigs, and insular carnivores: how exotic species turn native predators into prey. Proceedings of the National Academy of Sciences of the United States of America 99: 791-796.

Rout, T.M., Moore, J.L., Possingham, H.P. \& McCarthy, M.A. (2011) Allocating biosecurity resources between preventing, detecting, and eradicating island invasions. Ecological Economics 7: 54-62.

Russell, J.C. (2011) Indirect effects of introduced predators on seabird islands. In: Seabird Islands: Ecology, Invasion, and Restoration, eds. C.P.H. Mulder, W.B. Anderson, D.R. Towns \& P.J. Bellingham, pp. 261-279. New York, NY, USA: Oxford University Press. 
Russell, J.C. (2014) A comparison of attitudes towards introduced wildlife in New Zealand in 1994 and 2012. Fournal of the Royal Society of Nem Zealand 44: 136-151.

Russell, J.C., Cole, N.C., Zuël, N. \& Rocamora, G. (2016) Introduced mammals on Western Indian Ocean islands. Global Ecology and Conservation 6: 132-144.

Russell, J.C. \& Holmes, N.D. (2015) Tropical island conservation: rat eradication for species recovery. Biological Conservation 185: $1-7$.

Russell, J.C. \& Blackburn, T.M. (2017) Invasive alien species: denialism, disagreement, definitions and dialogue. Trends in Ecology E Evolution 32: 312-314.

Russell, J.C. \& Broome, K.G. (2016) Fifty years of rodent eradications in New Zealand: another decade of advances. New Zealand Fournal of Ecology 40: 197-204.

Russell, J.C., Taylor, C.N. \& Aley, J. P (in press) Social assessment of inhabited islands for wildlife management and eradication. Australasian Fournal of Environmental Management.

Saunders, A. \& Norton, D.A. (2001) Ecological restoration at mainland islands in New Zealand. Biological Conservation 99: 109_ 119.

Sax, D.F. \& Gaines, S.D. (2003) Species diversity: from global decreases to local increases. Trends in Ecology E Evolution 18: 561-566.

Schmitz, M.F., Arnaiz-Schmitz, C., Herrero-Jáuregui, C., Díaz, P., Matos, D.G.G. \& Pineda, F.D. (in press) People and nature in the Fuerteventura Biosphere Reserve (Canary Islands): socioecological relationships under climate change. Environmental Conservation.

Secord, D. \& Kareiva, P. (1996) Perils and pitfalls in the host specificity paradigm. BioScience 46: 448-453.

Seebens, H., Blackburn, T.M., Dyer, E., Genovesi, P., Hulme, P.E., et al. (2017) No saturation in the accumulation of alien species worldwide. Nature Communications 8: 14435.

Shapiro, H.G., Peterson, M.N., Stevenson, K.T., Frew, K.N. \& Langerhans, R.B. (in press) Wildlife species preferences differ among children in continental and island locations. Environmental Conservation.

Shea, K. \& Chesson, P. (2002) Community ecology theory as a framework for biological invasions. Trends in Ecology E Evolution 17: $170-176$.

Simberloff, D. (2000) Extinction-proneness of island species - causes and management implications. Raffles Bulletin of Zoology 48: 1-9.

Simberloff, D. (2001) Eradication of island invasives: practical actions and results achieved. Trends in Ecology \& Evolution 16: 273-274.

Simberloff, D. (2006) Risk assessments, blacklists, and white lists for introduced species: are predictions good enough to be useful? Agricultural and Resource Economics Reviem 35: 1-10.

Simberloff, D. \& Stiling, P. (1996) Risks of species introduced for biological control. Biological Conservation 78: 185-192.

Tershy, B.R., Shen, K.W., Newton, K.M., Holmes, N.D. \& Croll, D.A. (2015) The importance of islands for the protection of biological and linguistic diversity. BioScience 65: 592-597.
Timmins, S.M. \& Braithwaite, H. (2002) Early detection of invasive weeds on islands. In: Turning the Tide: The Eradication of Invasive Species, eds. C.R. Veitch \& M.N. Clout, pp. 311-318. Gland, Switzerland and Cambridge, UK: IUCN SSC Invasive Species Specialist Group, IUCN.

Tobin, P.C., Kean, J.M., Suckling, D.M., McCullough, D.G., Herms, D.A. \& Stringer, L.D. (2014) Determinants of successful arthropod eradication programs. Biological Invasions 16: 401414.

Towns, D.R., Atkinson, I.A. \& Daugherty, C.H. (2006) Have the harmful effects of introduced rats on islands been exaggerated? Biological Invasions 8: 863-891.

Traveset, A., Kueffer, C. \& Daehler, C.C. (2014) Global and regional nested patterns of non-native invasive floras on tropical islands. Journal of Biogeography 41: 823-832.

Uyarra, M.C., Cote, I.M., Gill, J.A., Tinch, R.R., Viner, D. \& Watkinson, A.R. (2005) Island-specific preferences of tourists for environmental features: implications of climate change for tourism-dependent states. Environmental Conservation 32: 11-19.

Vitousek, P.M. (1988) Diversity and biological invasions of oceanic islands. In: Biodiversity, eds. E.O. Wilson \& F.M. Peter, pp. 181189. Washington, DC, USA: National Academy Press.

Van Driesche, R.G., Pratt, P.D., Center, T.D., Rayamajhi, M.B., Tipping, P.W., et al. (2016) Cases of biological control restoring natural systems. In: Integrating Biological Control into Conservation Practice, eds. R. Van Driesche, D. Simberloff, B. Blossey, C. Causton, M. Hoddle, C. Marks, K. Heinz, D. Wagner \& K. Warner, pp. 208-246. Chichester, UK: Wiley Blackwell.

van Kleunen, M., Dawson, W., Essl, F., Pergl, J., Winter, M., et al. (2015) Global exchange and accumulation of non-native plants. Nature 525: 100-103.

Veltman, C.J., Nee, S. \& Crawley, M.J. (1996) Correlates of introduction success in exotic New Zealand birds. The American Naturalist 147: 542-557.

Walker, B. \& Meyers, J. (2004) Thresholds in ecological and socialecological systems: a developing database. Ecology and Society 9: 3 .

Westphal, M.I., Browne, M., MacKinnon, K. \& Noble, I. (2008) The link between international trade and the global distribution of invasive alien species. Biological Invasions 10: 391-398.

Wilkinson, P.F. (1987) Tourism in small island nations: a fragile dependence. Leisure Studies 6: 127-146.

Williamson, M. (1981) Island Populations. Oxford, UK: Oxford University Press.

Wilson, J.R., García-Díaz, P., Cassey, P., Richardson, D.M., Pyšek, P. \& Blackburn, T.M. (2016) Biological invasions and natural colonisations are different - the need for invasion science. NeoBiota 31: 87-98.

Witmer, G.W.\& Fuller, P.L. (2011) Vertebrate species introductions in the United States and its territories. Current Zoology 57: 559 567.

Young, H.S., Parker, I.M., Gilbert, G.S., Guerra, A.S. \& Nunn, C.L. (2017) Introduced species, disease ecology, and biodiversitydisease relationships. Trends in Ecology E Evolution 32: 41-54. 